\title{
Can Corporate Social Responsibility (CSR) Enhance Firm Performance
}

\author{
Wahidatul Husnaini ${ }^{1 *}$, Hidayatul Khusnah ${ }^{2}$ \\ ${ }^{I}$ Doctoral Program at the Faculty of Economics and Business, Airlangga University, Surabaya Indonesia and Lecturer \\ at the Faculty of Faculty of Economics and Business, Mataram University, Indonesia. \\ ${ }^{2}$ Doctoral Program at the Faculty of Economics and Business, Airlangga University, Surabaya Indonesia and Lecturer \\ at Accounting Department, Economic and Business Faculty, University of Nahdlatul Ulama Surabaya, Surabaya 60237, \\ Indonesia.
}

Corresponding author Email: wahidatul.husnaini-2018@feb.unair.ac.id

\begin{abstract}
Corporate Social Responsibility (CSR) is one way the responsibility of corporations to investors and stakeholders. This study aims to examine that CSR can enhance firm performance. Research observation consists of 79 manufacturing companies listed in the Indonesian Stock Exchange (BEI) and discloses CSR expenditure in the monetary period 2014-2017. The results of hypothesis testing based on linear regression indicate that CSRt (this year) decreases future firm performance $\left(\mathrm{ROA}_{t}+1\right)$.
\end{abstract}

Keywords: Corporate Social Responsibility (CSR), firm performance, Return on Asset (ROA).

\section{INTRODUCTION}

Corporate Social Responsibility (CSR) is becoming more critical to organizations in recent years. Organizations cannot ignore CSR for long-term sustainability becauseCSR focuses on the right business and focuses on environmentally friendly business. CSR activities accommodate the needs and interests of their stakeholders [1]. CSR Disclosure considered as wasting money but preferably on long-term investing [2].

CSR is a related legitimacy theory; the theory of legitimacy is a social contract between companies and society. Companies must ensure that they operate under society norms. CSR is a company tool to meet society's expectations towards the company by aligning the standards that exist in the community so that it is legitimate in society and stakeholders' views [3]. Support by [4] and [5] that the company's CSR activities uphold social-cultural norms, especially the environment, to gain legitimacy from the community and stakeholders.

Pressure from consumers and other stakeholders such as investors, employees, and the community causes anincrease in CSR demand. [6]. CSR is related to business ethics, company performance, and corporate accountability [7]. According to [8], CSR trends driven by ethical demands and other companies' tasks, such as making profitand growing and maximizing shareholder value. Investments in socially responsible activities provide a higher return than profit-maximizing [9].

The research on the relationship between CSR and company performance shows mixed results. CSR not only improves the firm's social value and reputation but also improves profitability, performance, sales, market share, stock return and ROA [10] [11] [12] [13] [14] [15]. No relationship [6]. Dkhili \& Ansi [16] explained 
that social responsibility has no impact on financial performance measured by ROA. The negative relationship shown by [17] [18] and [19], [20] showed that CSR decreased ROA and stock return although CSR in China and India is mandatory,

Based on the inconsistent results between one researchwith another, this research aims to examine that CSR can enhance firm performance, especially future firm performance. We argue that CSR activities can improve firm performance, as measured by ROAt +1 . CSR activities give investors and stakeholders a signal that the company complies with the rules even though CSR is still voluntary in Indonesia, which increases the trust of shareholders and stakeholders, which ultimately increases the company's performance in the future.

\section{HYPOTHESIS DEVELOPMENT}

CSR is one way to minimize conflicts with stakeholders [21] because it reduces information asymmetry between management and shareholders [22]. Following agency theory, information asymmetry between management and shareholders can reduce by disclosing CSR.

The signaling theory explained the relationship between CSR and company performance. Signal theory make changes to the behavior of shareholders and stakeholder if companies disclosure information. Information can give signals for shareholders and stakeholders that the company has a good/bad prospect in the future. Lys et al [23] explained that the signaling hypothesis predicts that positive (negative) values of the deviation are associated with positive (negative) future performance.

CSR activities provide an excellent signal to investors and stakeholders that the company follows the rule, ethical responsibility to ensure that the company operates within legal boundaries for long-term business performance and sustainability. According to Mishra \& Suar [24], the company sends a strong signal about CSRcommitments to improve firm performance.

ROA, as a measure of company performance, has the advantage of a higher level of comparison between companies and all companies in one industry. [25] and consistent as an authentic measure of company performance, as cited by Mishra and Suar (2010) [24]. The higher ROA shows the higher implies value creation for shareholders [24]

CSRt will improve the company's performance in the future (Lys et al., 2015). CSR increases ROA in the future $\left(\mathrm{CSR}_{t+1}-\mathrm{CSR}_{t+4}\right)$ [26]. Based on this explanation, theresearch hypotheses proposed are: future

H: CSR can enhance firm performance in the

\section{METHODOLOGY}

\subsection{Data Collection}

Data were collected from 79 manufacturing companies listed on the Indonesia Stock Exchange for the financial year 2014-2017 and have CSR expenditure data in monetary (Rupiah). The manufacturing company's choiceis because it has assetheavy so that ROA is a better indicator of company performance [24].

\subsection{Variables and Measurements}

The dependent variable in this study is firm performance, measured by ROAt +1 . The use of $\mathrm{ROAt}+1$ (future performance) based on [27]. ROAt +1 , as a measure of accounting performance, is more able to predict CSR than market performance. The independent variable is the log CSR expenditure.

We use two control variables are firm size and leverage. Larger firms to receive more press attention [26] [23] [20]. Higher leverage contributes to higher profitability and makes more social spending [20].

ROA = Income before extraordinary items divided by totalassets, measured at the end of fiscal year $t$ (Lys et al.,2015) [23]

Size $=$ Natural logarithm of total assets, measured at the end of fiscal year $t$ (Lys et al., 2015) [23]

Leverage $=$ Sum of long-term debt and debt in current liabilities divided by total assets, measured at the end of fiscal year t (Lys et al., 2015) [23]

\subsection{The empirical model}

A research model for hypothesis testing uses the following equation:

$\mathrm{ROA}_{i, t \$ 1}=\alpha_{\&}+\beta_{1} \operatorname{CSR}_{i, t}+\beta_{2} \operatorname{Size}_{i, t}+\beta_{\left(\operatorname{Lev}_{i, t}\right.}+\mathrm{e}$

\section{RESULT AND DISCUSSION}

The data analyzed 79 firm-year observations of listed companies manufacturing from 2014 - 2017. The descriptive statistics results in Table 1. 
Table 1 Descriptive Statistics

\begin{tabular}{|l|r|r|r|r|r|}
\hline & $\mathrm{N}$ & \multicolumn{1}{|c|}{ Minimu } & Maximu & \multicolumn{1}{|c|}{ Mean } & \multicolumn{1}{c|}{$\begin{array}{c}\text { Std. } \\
\text { Deviation }\end{array}$} \\
\hline ROAt+1 & 79 & -.075 & .401 & .113 & .100 \\
CSRt & 79 & 17.034 & 26.953 & 21.898 & 2.456 \\
Sizet & 79 & 24.816 & 33.941 & 29.483 & 2.667 \\
LEVt & 79 & .158 & 2.992 & .514 & .398 \\
Valid N & 79 & & & & \\
(listwise) & & & & & \\
\hline
\end{tabular}

Table 1 explains that ROAt+1 indicates that the average of the companies in the sample is profitable relative to its total assets, meaning that the management's company is efficient in using its assets to generate earnings. Table 1 also shows that the average of all of the sample is disclosure CSR expenditure and large firm size. Leverage indicates that the company able to pay debt obligations relatives to its total asset.

Table 2 Regression result

\begin{tabular}{rrlcll}
\hline & Model & \multicolumn{4}{l}{ Unstandardized Coefficients } \\
\hline \multirow{2}{*}{1} & Variables & B & Std. Error & $\mathrm{t}$ & Sig. \\
& (Constant) & .550 & .100 & -5.471 & .000 \\
& CSRt & -.017 & .006 & -2.839 & .006 \\
& Sizet & .034 & .006 & 6.223 & .000 \\
& Levt & .047 & .022 & 2.095 & .040 \\
\hline $\mathrm{R}^{2}:$ & & F-value : 17.936 & & $\rho$-value & \\
$42 \%$ & & & & 0.000 & \\
\hline
\end{tabular}

Based on the empirical model in table 2, CSR this year has a significant negative impact on future firm performance. This result rejects the hypothesis even though it has asignificant effect since the direction is in contrast with the proposed hypothesis. CSR this year is bad news for investors, it means terrible prospects for future performance. Investors and stakeholders view CSR this year in Indonesia focuses only on charity and social activities such as education and only fulfills CSR obligations to reduce the company's performance in the future. Current conditions indicate that CSR is not only related to social activities, but investors react more when companies care about the environment because the company primarily causes environmental damage/pollution that occurs. This study's results support research [17] [18] and [19], [20]. Our finding contradicts the findings [10] [11] [12] [13] [14] [15] which states that CSR improves company performance and [6] [16] explained that social responsibility has no impact on financial performance measured by ROA.

This research also supports the signal theory that good news and bad news information issued by companies affect the behavior of investors and stakeholders, CSR issued by companies decreases the company's future performance $(\mathrm{ROAt}+1)$.

Firm size and leverage this year improve future firm performance $(\mathrm{ROAt}+1)$, large firm size has more significant resources for CSR expenditure and, therefore, engages in CSR-related activities to improve company performance in the future [23]. Companies with high debt tend to spend CSR expenditure on reducing information asymmetry with lenders and using debt to increase profitability in the future to improve company performance in the future [20].

\section{CONCLUSION}

The objective of this study is to analyze CSR this year can enhance future firm performance. The result of this study shows that CSR expenditure this year cannot improve future firm performance. CSR expenditure this year decreases future firm performance, which implies that investors and stakeholders reacted negatively to CSR expenditure, thereby reducing company performance. CSR conducted by the company so far is the only social activity and only to negate the obligation that the company has carried out CSR activities so that 
investors assume that CSR activities are a burden for the company that reduces the company's profit.

\section{REFERENCES}

[1] N. Kamatra and E. Kartikaningdyah, 'Effect corporate social responsibility on financial performance', Int. J. Econ. Financ. Issues, vol. 5,pp. 157-164, 2015.

[2] K. Dewi and M. Monalisa, 'Effect of Corporate Social Responsibility Disclosure on Financial Performance with Audit Quality as a Moderating Variable', Binus Bus. Rev., vol. 7, no. 2, pp. 149-155, 2016, doi: 10.21512/bbr.v7i2.1687.

[3] J. Dowling and J. Pfeffer, 'Organizational Legitimacy: Social Values and Organizational Behavior', Pac. Sociol. Rev., vol. 18, no. 1, pp. 122-136, 1975, doi: 10.2307/1388226.

[4] G. Palazzo and A. G. Scherer, 'Corporate legitimacy as deliberation: A communicative framework', J. Bus. Ethics, vol. 66, pp. 71-88, 2006, doi: 10.1007/s10551-006-9044-2.

[5] X. Luo and C. B. Bhattacharya, 'Corporate Social Responsibility, Customer Satisfaction, and Market Value', J. Mark., vol. 70, pp. 1-18, 2006, doi: 10.1509/jmkg.70.4.001.

[6] A. Mcwilliams and D. Siegel, 'Corporate Social Responsibility: A Theory of the Firm Perspective Authors ( s ): Abagail McWilliams and Donald Siegel Source: The Academy of Management Review, Vol . 26, No . 1 ( Jan ., 2001 ), pp . 117-127 Published by: Academy of Management Stable', Acad. Manag. Rev., vol. 26, no. 1, pp. 117-127, 2001.

[7] H. Elasrag, Corporate Social Responsibility: An Islamic Perspective, no. 67537. M P RA Munich Personal RePEc Archive, 2015.

[8] K. Sahlin-Andersson, 'Corporate social responsibility: A trend and a movement, but of what and for what?', Corp. Gov., vol. 6, no. 5, pp. 595-608, 2006, doi: 10.1108/14720700610706081.

[9] A. Mackey, T. B. Mackey, and J. B. Barney, 'Corporate social responsibility and firm performance: Investor preferences and corporate strategies', Acad. Manag. Rev., vol. 32, no. 3, pp. $\quad 817-835, \quad 2007, \quad$ doi: 10.5465/AMR.2007.25275676.

[10] J. Cherian, M. Umar, P. A. Thu, T. NguyenTrang, M. S. Sial, and N. V. Khuong, 'Does corporate social responsibility affect the financial performance of the manufacturing sector? Evidence from an emerging economy', Sustain., vol. 11, no. 4, pp. 1-14, 2019, doi: 10.3390/su11041182.

[11] S. J. Cho, C. Y. Chung, and J. Young, 'Study on the relationship between CSR and financial performance', Sustain., vol. 11, pp. 1-26, 2019, doi: 10.3390/su11020343.

[12] J. C. Evans, 'The Influence of Corporate Social Responsibility', J. Appl. Account. Tax., vol. 2, no.1, pp. 54-50, 2017.

[13] S. Famiyeh, 'Corporate social responsibility and firm's performance: Empirical evidence', Soc. Responsib. J., vol. 13, no. 2, pp. 390-406, 2017, doi: 10.1108/SRJ-04-2016-0049.

[14] W. S. Wan Ahamed, M. K. Almsafir, and A. W. Al-Smadi, 'Does Corporate Social ResponsibilityLead to Improve in Firm Financial Performance? Evidence from Malaysia', Int. J. Econ. Financ., vol. 6, no. 3, pp. 126-138, 2014, doi: 10.5539/ijef.v6n3p126.

[15] S. A. Waddock and S. B. Graves, 'the Corporate Social Performance-Financial Performance Link',Strateg. Manag. J., vol. 18, no. 4, pp. 303319, 1997, doi: 10.1108/IJCHM-04-2017-0195.

[16] H. Dkhili and H. Ansi, 'The Link between Corporate Social Responsibility and Financial Performance: The Case of the Tunisian Companies', J. Organ. Knowl. Manag., vol. 2012,pp. 1-11, 2012, doi: 10.5171/2012.640106.

[17] P. Wright and S. P. Ferris, 'Agency Conflict and Corporate Strategy: the Effect of Divestment on Corporate Value', Strateg. Manag. J., vol. 18, pp. 77-83, 1997, doi: 10.1002/(sici) $1097-$ 0266(199701)18:1<77::aid-smj810>3.3.co;2-i.

[18] W. Husnaini, E. E. Sasanti, and S. R. Cahyaningtyas, 'Corporate Social Responsibility (CSR) dan Reputasi Perusahaan', J. Apl. Akunt., vol. 2, no. 2, pp. 1-9, 2018, doi: 10.29303/jaa.v2i2.22.

[19] Y. C. Chen, M. Hung, and Y. Wang, 'The effect of mandatory CSR disclosure on firm profitability and social externalities: Evidence from China', J. Account. Econ., vol. 65, no. 1, pp. 169-190, 2018, doi: 10.1016/j.jacceco.2017.11.009.

[20] A. Bhattacharyya and M. L. Rahman, 'Mandatory CSR expenditure and stock return', Meditari Account. Res., 2020, doi: 10.1108/MEDAR-10- 2019-0591.

[21] L. Becchetti, R. Ciciretti, I. Hasan, and N. Kobeissi, 'Corporate social responsibility and shareholder's value', J. Bus. Res., vol. 65, no. 11, pp. 1628-1635, 2012, doi: 10.1016/j.jbusres.2011.10.022.

[22] G. Gavana, P. Gottardo, and A. M. Moisello, 'The effect of equity and bond issues on sustainability disclosure. Family vs non-family Italian firms', Soc. Responsib. J., vol. 13, no. 1, pp. 126-142, 2017, doi: 10.1108/SRJ-05-20160066. 
[23] T. Lys, J. P. Naughton, and C. Wang, 'Signaling through corporate accountability reporting', $J$. Account. Econ., vol. 60, pp. 56-72, 2015, doi: 10.1016/j.jacceco.2015.03.001.

[24] S. Mishra and D. Suar, 'Does corporate social responsibility influence firm performance of Indian companies?', J. Bus. Ethics, vol. 95, pp. 571-601, 2010, doi: 10.1007/s10551-010-04411.

[25] E. W. Anderson, C. Fornell, and S. K. Mazzvancheryl, 'Customer Satisfaction and Customer Value', J. Mark., vol. 68, no. October, pp. 172-185, 2004, doi:
10.1142/9789814641371_0006.

[26] H. Servaes and A. Tamayo, 'The impact of corporate social responsibility on firm value: The role of customer awareness', Manage. Sci., vol. 59, pp. 1045-1061, 2013, doi: 10.1287/mnsc. 1120.1630 .

[27] J. B. McGuire, A. Sundgren, and T. Schneeweis, 'Corporate Social Responsibility and Firm Financial Performance', Acad. Manag. J., vol. 31, no. 4, pp. 854-872, 1988, doi: $10.5465 / 256342$ 